\title{
Comparison of different media for bacteriocine typing of Proteus mirabilis
}

\author{
R. H. GEORGE
}

From the Department of Virology, The Medical School, Birmingham

SYNOPSIS The effect of a variety of nutrient bases on the production of bacteriocines by 10 standard Cradock-Watson types of Proteus mirabilis has been investigated. Differences in yield of greater than 10000 fold were observed. Maximum yields were obtained with proteose peptone no. 3 (Difco) and a medium containing this with oxgall (Difco) as an antiswarming agent was developed for routine typing.

The typing of Proteus species by bacteriocine production was described by Cradock-Watson in 1965. Since then the panel of indicator strains has been increased to twenty-four. The proportion of isolates active against these indicators has varied in different series, with reports of $6 \%$ (Tracy and Thomson, 1972), 0 to $76 \%$ when using different media (Phillips, 1974), and 59\% until recently in my own hands. This compares with a figure of approximately $80 \%$ obtained with strains referred to the Cross-Infection Reference Laboratory, Colindale (Pitt, 1973).

It is known that in colicine typing of Escherichia coli the pattern of inhibition of indicator strains depends upon the titres of colicine produced (McGeachie and McCormick, 1967) and that colicine production is affected by changes in the composition of the medium (Papavassiliou, 1963; McGeachie and McCormick, 1963).

Because of these reports I have investigated the effect of the composition of the medium on bacteriocine titres and bacteriocine typing of strains of $\boldsymbol{P}$. mirabilis.

\section{Materials}

STRAINS OF $P$. mirabilis

Producer strains of Cradock-Watson types CW1- 10 and indicator strains 1-24 (supplied by T. L. Pitt, Cross-Infection Reference Laboratory, Colindale). Thirty-three organisms of known serotype, resistotype, bacteriophage type and previously tested for bacteriocine production on MacConkey agar (Colindale) supplied by J. de Louvois, Edgware General Hospital and 119 consecutive isolates from Dudley Received for publication 10 September 1974.
Road Hospital, Birmingham (supplied by Dr J. D. Williams).

\section{MEDIA}

Fluid media 1-13 in which bacteriocines were induced Nutrient bases 1-9 were selected so as to include those found useful for the production of colicines by McGeachie and McCormick (1963). Subsequently a variety of antiswarming agents were added to the nutrient base in which the highest titres of bacteriocines had been obtained to produce media 10-13.

1 Neopeptone (Difco) $10 \mathrm{~g} /$ litre

2 Proteose peptone (Difco) $10 \mathrm{~g} /$ litre

3 Proteose peptone no. 2 (Difco) $10 \mathrm{~g} /$ litre

4 Proteose peptone no. 3 (Difco) $10 \mathrm{~g} /$ litre

5 Proteose peptone no. 4 (Difco) $10 \mathrm{~g} /$ litre

6 Bacto peptone (Difco) $10 \mathrm{~g} /$ litre

7 Bacteriological peptone (Oxoid) $10 \mathrm{~g} /$ litre

8 Peptone (Oxoid L34) $10 \mathrm{~g} /$ litre

All these media contained sodium chloride $5 \mathrm{~g} /$ litre and were adjusted to $\mathrm{pH} 7 \cdot 4$.

9 Hartleys digest broth (Oxoid)

10 Proteose peptone no. 3 (Difco) $20 \mathrm{~g} /$ litre with added $\mathrm{NaCl} 5 \mathrm{~g} /$ litre and oxgall (Difco) $4 \mathrm{~g} /$ litre

11 Proteose peptone no. 3 (Difco) $20 \mathrm{~g} /$ litre with added $\mathrm{NaCl} 5 \mathrm{~g} /$ litre and sodium desoxycholate (Oxoid) $2 \mathrm{~g} /$ litre

12 Proteose peptone no. 3 (Difco) $20 \mathrm{~g} /$ litre with added $\mathrm{NaCl} 5 \mathrm{~g} /$ litre and bile salt (Difco) $5 \mathrm{~g} /$ litre

13 Proteose peptone no. 3 (Difco) $20 \mathrm{~g} /$ litre with added $\mathrm{NaCl} 5 \mathrm{~g} /$ litre, oxgall (Difco) $4 \mathrm{~g} /$ litre, and lactose (BDH) $10 \mathrm{~g} /$ litre.

Composition of solid media from which bacteriocines were extracted

Peptone as described in fluid media 1-7 (20 g/litre) 
with added lactose (10 g/litre), bile salt (Oxoid, $5 \mathrm{~g} /$ litre), $\mathrm{NaCl}$ ( $5 \mathrm{~g} /$ litre), and solidified with agar (Difco, $12 \mathrm{~g} /$ litre), also MacConkey agar (Colindale, kindly supplied by T. L. Pitt).

\section{Media used for routine typing method}

These were selected so as to include the original medium used by Cradock-Watson (1965) and the medium previously enabling the greatest number of strains to be typed (MacConkey agar, Colindale). A solid medium was developed from the fluid medium containing an antiswarming agent, in which the highest titres of bacteriocines had previously been produced.

14 MacConkey agar (Oxoid)

15 MacConkey agar (Colindale)

16 MacConkey agar (BBL)

17 Proteose peptone no. 3 (Difco) $10 \mathrm{~g} /$ litre, $\mathrm{NaCl} 5 \mathrm{~g} /$ litre, oxgall (Difco) $4 \mathrm{~g} /$ litre, solidified

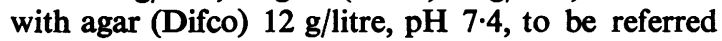
to as bacteriocine agar.

\section{Methods}

\section{INDUCTION OF BACTERIOCINES IN FLUID} MEDIA

Producer strains CW1 to CW10 were incubated for 18 hours at $30^{\circ} \mathrm{C}$ in $5 \mathrm{ml}$ volumes of media $1-13$ in $250 \mathrm{ml}$ conical flasks, so as to produce heavy growth. A further $45 \mathrm{ml}$ of the same medium together with mitomycin C (Kyowa Co Ltd) to give a final concentration of $1 \mu \mathrm{g} / \mathrm{ml}$ was added to each flask. Cultures were incubated at $30^{\circ} \mathrm{C}$ for 24 hours in a shaking waterbath. Two millilitres of chloroform was added to each flask, the cultures were shaken for five minutes, and the contents allowed to separate. The supernatant was centrifuged at $800 \mathrm{~g}$ for 10 minutes and irradiated with short-wave ultraviolet to destroy bacteriophage, the presence of which is likely to reduce specificity of bacteriocine typing, as described by Rampling and Whitby (1972), receiving a total dose of $0.63 \mathrm{~J} / \mathrm{cm}^{2}$. A pair of susceptible indicator organisms were chosen for: each bacteriocine type and were surface-inoculate on plates of bacteriocine agar. Serial tenfold diluo tions of the bacteriocine-containing cultures wer made in fluid medium no. 3 and spotted onto these plates, which were incubated at $37^{\circ} \mathrm{C}$ for 18 hours.

\section{PRODUCTION AND EXTRACTION OF}

\section{BACTERIOCINES FROM SOLID MEDIA}

The method of freezing and thawing described b. McGeachie and McCormick (1963) was used to extract bacteriocines from solid media which has been lawned with producers CW1 to CW10 and incubated at $37^{\circ} \mathrm{C}$ for 24 hours. Titrations werk performed on the same medium as that utilized for production, by the method described above.

\section{ROUTINE BACTERIOCINE TYPING}

The method of Abbott and Shannon (1958) but with growth of producers for 24 hours at $37^{\circ} \mathrm{C}$ was used. Producer strains CW1 to CW10 were typed on media $14,15,16$, and 17 . Thirty-three organisms which had previously been typed at the CrossInfection Reference Laboratory, Colindale, ow MacConkey agar (Colindale), were retested of MacConkey agar (Oxoid) and bacteriocine agar an a further 119 organisms were typed on these las two media.

\section{Results}

\section{INDUCTION OF BACTERIOCINES IN FLUID} MEDIA

The titre of bacteriocines from producers CW1 to CW10 showed marked variation according to the composition of the medium (table I). Medium 4 (proteose peptone no. 3, Difco) consistently showe good titres whereas most others showed variation between one producer and another. The addition of antiswarming agents to this nutrient base reduce the titres of bacteriocines obtained (table II).

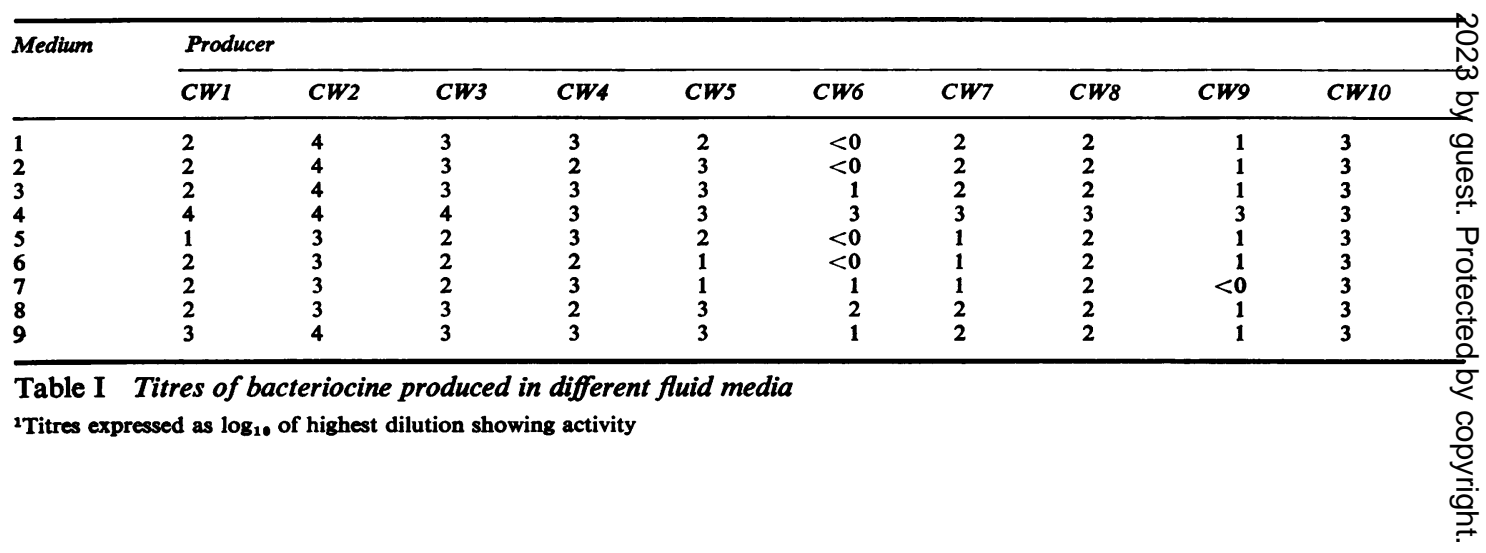




\begin{tabular}{|c|c|c|c|c|c|c|c|c|c|c|c|}
\hline Medium & Additive & $C W I$ & $C W 2$ & $C W 3$ & $C W 4$ & $C W 5$ & $C W 6$ & $C W 7$ & $C W 8$ & $C W 9$ & $C W 10$ \\
\hline 4 & Nil & 4 & 4 & 4 & 3 & 3 & 3 & 3 & 3 & 3 & 3 \\
\hline 10 & Oxgall & 3 & 3 & 3 & 3 & 3 & 3 & 3 & 3 & 2 & 3 \\
\hline 11 & Sodium desoxycholate & 2 & 3 & 3 & 2 & 3 & 2 & 2 & 2 & $<0$ & 3 \\
\hline 12 & Bile salt & $\mathbf{0}$ & 2 & $<0$ & 3 & 3 & 2 & 2 & 2 & $<0$ & 3 \\
\hline 13 & Oxgall and lactose & 3 & 3 & 3 & 3 & 3 & 3 & 3 & 2 & 2 & 3 \\
\hline
\end{tabular}

Table II Effect of antiswarming agents on bacteriocine titres ${ }^{1}$

${ }^{1}$ Titres expressed as $\log _{10}$ of highest dilution showing activity

\begin{tabular}{llllllllllll}
\hline Medium & CW1 & CW2 & CW3 & CW4 & CW5 & CW6 & CW7 & CW8 & CW9 & CW10 \\
\hline 14 & +1 & + & + & $\pm^{2}$ & + & + & + & -3 & - & + \\
15 & + & + & + & + & + & + & + & + & + & + \\
16 & + & + & + & + & + & + & \pm & \pm & - & + \\
17 & + & + & + & + & + & + & + & + & + & + \\
\hline
\end{tabular}

Table III Comparison of media for typing producers CWI-10

$1+=$ bacteriocine giving standard pattern of inhibition with indicators

$\pm=$ bacteriocine giving altered pattern of inhibition with indicators

3- = bacteriocine not detected

Sodium desoxycholate and bile salt inhibited production by producer CW9 and reduced the titres obtained with the other producers. The addition of oxgall reduced titres to a lesser extent and lactose made little difference to the titre obtained.

Further studies have shown that modification of the method of bacteriocine induction in fluid media can increase bacteriocine production much above the levels of tables I and II with titres of the order of $10^{5}$ to $10^{9}$ (see discussion).

\section{EXTRACTION OF BACTERIOCINES FROM SOLID MEDIA}

No bacteriocine activity was detected in extracts obtained by freezing and thawing with producers CW1 to CW10 from any of the media.

\section{ROUTINE TYPING OF $P$. mirabilis}

The production of bacteriocine was detected in all strains CW1 to CW10 on MacConkey agar (Colindale) and bacteriocine agar. Four strains either failed to produce bacteriocine or gave an altered pattern of inhibition on the other two varieties of MacConkey agar (table III). Detection of bacteriocine in the remaining 152 strains is illustrated in

\begin{tabular}{lllll}
\hline Medium & $\begin{array}{l}\text { 33 Organisms } \\
\text { (Number } \\
\text { Typable) }\end{array}$ & $\begin{array}{l}119 \text { Organisms } \\
\text { (Number } \\
\text { Typable) }\end{array}$ & $\begin{array}{l}\text { Both Groups } \\
152 \text { (Number } \\
\text { Typable) }\end{array}$ & $\begin{array}{l}\text { Percentage } \\
\text { Typable }\end{array}$ \\
\hline 14 & 23 & 71 & 94 & 62 \\
15 & 31 & $\frac{1}{71}$ & $\frac{1}{21}$ & $\overline{79}$ \\
\hline
\end{tabular}

Table IV Production of bacteriocine detected by routine typing table IV. Whereas $79 \%$ were typable on bacteriocine agar only $62 \%$ were typable on MacConkey agar (Oxoid). In the series of 33 organisms with similar patterns of inhibition on MacConkey agar (Colindale) and bacteriocine agar, bacteriocine production was detected in 31 organisms.

\section{Discussion}

The effect of the composition of the medium on bacteriocine production is clearly demonstrated in tables I and II, and its relevance to routine typing in tables III and IV.

Failure to detect bacteriocine by the freezing and thawing method of McGeachie and McCormick (1963) has also been reported by Tracy and Thomson (1972). It is probable that inclusion of bile salt (Oxoid) as an antiswarming agent in all the media suppressed bacteriocine production, and other studies have since demonstrated that high titres of bacteriocines cannot be obtained at $37^{\circ} \mathrm{C}$. Preliminary studies have also shown that some bacteriocines are destroyed by freezing, and further studies on the effect of this and other agents on bacteriocines of $P$. mirabilis are in progress.

The actual titre of bacteriocine obtainable is higher than illustrated in tables I and II, as some bacteriocine in addition to bacteriophage is destroyed by the dose of ultraviolet irradiation used in these studies. Titres of bacteriocines obtained in proteose peptone no. 3 (Difco) are two to four-fold greater before irradiation. Subsequent studies have shown that the addition of fluid medium no. 4 to the inoculum and agitation of the culture for one hour before the addition of the mitomycin enables titres of $10^{9}$ to 
be obtained with some producer strains. Using these high titre extracts it has been possible to demonstrate that susceptible indicators may vary in their sensitivity by as much as ten thousand-fold. This emphasizes the necessity to obtain efficient bacteriocine production. McGeachie and McCormick (1963) demonstrated similar effects of the titre of bacteriocines with $E$. coli.

The effect of temperature on bacteriocine production by $\boldsymbol{P}$. mirabilis has also been investigated, and, in common with bacteriocines produced by other organisms, it appears that higher titres are obtained at temperatures lower than $37^{\circ} \mathrm{C}$. However, the greater tendency to swarm at these lower temperatures precludes their use in routine typing methods on solid media.

Phillips (1974) has shown differences in bacteriocine production from 0 to $76 \%$ with different media using a modification of the method of Abbott and Shannon (1958). Using a method similar to the broth induction method reported here, Al-Jumaili (1974) has detected bacteriocine production by $85 \%$ of over 600 isolates of $P$. mirabilis, although titres obtained in his studies were much lower than those reported here. Although the use of bacteriocine agar has led to a reduction in the number of strains which are untypable, there are still an appreciable number of strains for which the method has no application. An alternative scheme based on the sensitivity of strains to high-titre extracts is being developed by the author, but as yet a panel extracts which enables differentiation into a large number of strains with few or no untypable straies is not available.

The improvement in the present typing methơ using bacteriocine agar should encourage its mo\& frequent application, but the use of two typing methods is preferable, as it allows a greater proportion of strains to be typed (Kashbur, George, and Ayliffe, 1974).

\section{References}

Abbott, J. D., and Shannon, R. (1958). A method for typing Shige sonnei using colicine production as a marker. J. clin. Path., $\mathbf{t}$ $71-77$.

Al-Jumaili, I. J. (1974). Personal communication.

Cradock-Watson, J. E. (1965). The production of bacteriocines Proteus species. Zhl. Bact., I. Abt. Orig., 196, 385-388.

Kashbur, I. M., George, R. H., and Ayliffe, G. A. J. (1974). Resist typing of Proteus mirabilis and a comparison with otker methods of typing. J. clin. Path., 27, 572-577.

McGeachie, J., and McCormick, W. (1963). Comparison of colicion production and diffusion on different solid media. J. clin. Pat尽,
16, 278-280.

McGeachie, J., and McCormick, W. (1967). Importance of potenet in typing by colicine production. J. clin. Path., 20, 887-891.

Papavassiliou, J. (1963). Preparation and lyophilization of colicion suspensions. 1. Production of colicines in liquid nutrien media. Path. et Microbiol. (Basel), 26, 74-83.

Phillips, I. (1974). Personal communication.

Pitt, T. L. (1973). Personal communication.

Rampling, A., and Whitby, J. L. (1972). Preparation of phage-free pyocin extracts for use in the typing of Pseudomonas aerugino J. med. Microbiol., 5, 305-312.

Tracy, O., and Thomson, E. J. (1972). An evaluation of three metho@. of typing organisms of the genus Proteus. J. clin. Path., 25. 69-72. 